\title{
Radionuclide Decorporation Agent
}

National Cancer Institute

\section{Source}

National Cancer Institute. Radionuclide Decorporation Agent. NCI Thesaurus. Code C120558.

Any agent that is able to prevent absorption or facilitate the removal of internal radionuclide contamination. 